\title{
Impact of nitrogen and spacing on the growth and yield of okra [Abelmoschus esculentus (L.) Moench]
}

\author{
Navdeep singh brar, ${ }^{\text {, }}$ Daljeet singh \\ Department of Vegetable Science, University College of Agriculture, Guru Kashi University, Talwandi Sabo (Bathinda)
}

\begin{abstract}
The present investigations entitled "Impact of nitrogen and spacing on the growth and yield of okra" was carried out during spring summer season 2015. The applications of nitrogen at $100 \mathrm{~kg} / \mathrm{ha}$ recorded higher yield attributes of the number of nods per plant, leaves per plant, internodes length, plant height, pod length, number of pods per plant, fruit yield per plant and total green pod yield per hectare. Nitrogen application upto125 $\mathrm{kg} / \mathrm{ha}$ significantly decrease the days to $50 \%$ flowering. The pod weight, pod length, number of nodes per plant, number of pods per plant, fruit yield per plant and total green pod yield per hectare increased higher with the optimum plant to plant spacing of $15 \mathrm{~cm}$. The data revealed the interaction between nitrogen level and plant density was present in case of plant growth and yield contributing characters of okra. Although the highest level interaction of $100 \mathrm{~kg} \mathrm{~N} / \mathrm{ha}$ with plant to plat spacing $15 \mathrm{~cm}$ produced the high number of nods per plant, pod weight, pod length, number of pods per plant, pod yield per plant and total green pod yield per hectare and the days to $50 \%$ flowering decreased was recorded with $125 \mathrm{~kg} \mathrm{~N} / \mathrm{ha}$ and plant to plant spacing $20 \mathrm{~cm}$. The highest gross return (Rs.94080) and net return (Rs.84621.3) were obtained from N125S20.
\end{abstract}

\section{Introduction}

Okra, Ablemoschus esculentus (L) Moench commonly known as lady's finger. Bamy, Bamia (Arabic) (Aldigawi, 1996), Bhindi (India), Ilash (Nigeria) Shigidi, A.I, 1994), belongs to the family Malvaceae.

Okra originated in Asia and Africa (Thomson and Kelly, 1979). It is widely distributed and cultivated in the tropics, sub-tropics and warmer portions of the temperate region of the world on a varying scale (Kochhar, 1986). India is one of the leading producers of okra with a production of 5.784 million tonnes year-1 from an area of 498 million ha. Although the productivity of Okra (NHB, 2014) in India is higher (11.6 tonnes ha-1) than world average productivity ( 7.35 tonnes ha-1) but lower than that of Egypt (15.70 tonnes ha-1). This is because of low yield due to frequent attacks of pests and diseases, especially the fruit and shoot borer and yellow vein mosaic virus (YVMV) according to Journal of Agricultural Technology (2012). Okra is an important summer vegetable crop grown an area of 3204 thousand hectors, yielding 33351 million tonnes in Punjab (NHB 2014).

There are four known domesticated species of Abelmoschus. Among these, A. esculentus (Common Okra) is most widely cultivated in South and East Asia. The Principle elements present in pods of okra are k, Na, $\mathrm{Mg}$ and $\mathrm{Ca}$. Presence of $\mathrm{Fe}, \mathrm{Zn}, \mathrm{Mn}$ and $\mathrm{Ni}$ also has been reported (Moyin-Jesu,2007). Fresh pods are low in calories (20 per $100 \mathrm{~g}$ ), including about $30 \%$ of the recommended levels of vitamin C (16 to $29 \mathrm{mg}$ ), 10 to 20 $\%$ of foliate (46 to $88 \mathrm{mg}$ ) and about $5 \%$ of Vitamin A (14 to 20 RAE)(NAP, 2006). Both pod skin and seeds are excellent source of Zinc (80ug/g)(Glew,1997; Cook et al., 2000). Pods and seeds are rich in Phenolic compounds with important biological properties (Arapirtsas, 2008). Fresh Okra pods are the most important vegetable source of viscous fiber, an important dietary component to lower cholesterol (Kendall and Senkins, 2004). Seed protein is rich in tryptophan $(94 \mathrm{mg} / \mathrm{g} \mathrm{N})$ and also contains adequate amounts of sulfur-containing amino acid (189 $\mathrm{mg} 1 \mathrm{~g} \mathrm{~N})$ a rare combination that makes okra seeds exceptionally useful in reducing human malnutrition (NAP, 2006). Okra seed flour has been used to supplement corn flour for a very long time in countries like Egypt to make better quality dough (Take el-Kitanb, 1947).

The source of $\mathrm{N}$ for crop production may affect the performance of the crop. There is therefore the need to synchronize crop N supply with crop demand (Pang and Letey, 2000). Depletion and or shortage of N indicate that either the crop will not able to maintain its leaf area expansion rate or cannot maintain its leaf and plant $\mathrm{N}$ concentration. Either of this will have effects on Crop growth and production of economic products.

The requirement of nitrogen which varies according to environmental conditions has to be determined by actual field trial for any particular soil and climate. Okra crop response to nitrogen is required dose of nitrogen for the highest fruit yield appeared in various books and journals ranges from 120 to $200 \mathrm{~kg} / \mathrm{ha}$ (Amjad et al.2001;

\footnotetext{
a Corresponding author: Navdeep.brar50@gmail.com
} 
Rahman et al, 1992; Paliwal et al, 1999; Verma and Batra 1999; Rashid, 1999).

Generally, increase in planting density results in increased yield per unit area till a certain limit (Weiner, 1990). Suitable plant spacing can lead to optimum seed yield whereas too high or too low plant spacing could result in relatively low yield and quality (Absar and Siddique, 1982). The plant spacing for okra production suggested by different authors ranges from 20 to $40 \mathrm{~cm}$ between plants and 30 to $60 \mathrm{~cm}$ between rows (Hossain et al, 1999; Rastagie et al, 1987; Thakur and Arora, 1986; Khan and Jaisal, 1988). Keeping this in view, the present work was, thus, under taken with the following objectives.

- To study the effect of Nitrogen fertilizer on yield and yield attributing characters of Okra

- To study effect of plant density on plant growth and green fruit yield

- To study benefit cost ratio analysis of okra as influenced by nitrogen and spacing

\section{Materials and Method}

The experiment was conducted at the research farm of Guru Kashi University Talwandi Sabo (Bathinda) during spring summer season 2015.

Table 1. Chemical analyses of the experimental field at sowing time.

\begin{tabular}{|c|c|c|c|}
\hline $\begin{array}{l}\text { Soil } \\
\text { properties }\end{array}$ & $\begin{array}{l}\text { Soil } \\
\text { Depth }\end{array}$ & Rating & $\begin{array}{l}\text { Method used for } \\
\text { estimation }\end{array}$ \\
\hline $\mathrm{pH}$ & 8.02 & High & $\begin{array}{lr}1: 2, \quad \text { soil: } & \text { water } \\
\text { suspension with } & \text { weckman glass } \\
\text { electrode pH meter } \\
\text { (Jackson 1973) }\end{array}$ \\
\hline $\mathrm{EC}\left(\mathrm{d} \mathrm{sm}^{-1}\right)$ & 0.589 & High & $\begin{array}{l}1: 2, \text { Soil: water } \\
\text { suspension with sol } \\
\text { bridge conductivity } \\
\text { meter (Jackson } \\
1973 \text { ) }\end{array}$ \\
\hline $\begin{array}{l}\text { Available } \\
\mathrm{N}\left(\mathrm{kg} \mathrm{ha}^{-1}\right)\end{array}$ & 225 & Medium & $\begin{array}{l}\text { Alkaline potassium } \\
\text { permanganate } \\
\text { method (Subbiah } \\
\text { and Asija 1956) }\end{array}$ \\
\hline $\begin{array}{l}\text { Available P } \\
\left(\mathrm{Kg} \mathrm{ha}^{-1}\right)\end{array}$ & 13 & Medium & $\begin{array}{l}0.5 \quad \mathrm{~N} \text { Sodium } \\
\text { bicarbonate } \\
\text { extracyalde } \mathrm{P} \\
\text { (Olsen et al } 1954)\end{array}$ \\
\hline $\begin{array}{l}\text { Available } \\
\mathrm{K}\left(\mathrm{Kg} \mathrm{ha}^{-1}\right)\end{array}$ & 138 & Medium & NH4OAC method \\
\hline $\begin{array}{l}\text { Textural } \\
\text { Class }\end{array}$ & $\begin{array}{l}\text { Sandy } \\
\text { Loam }\end{array}$ & & $\begin{array}{l}\text { International pipette } \\
\text { method (piper } \\
1966 \text { ) }\end{array}$ \\
\hline
\end{tabular}

The chemical analyses of the soil along with the method used for their determination before sowing are presented in the Table. Two factors experiment was laid out in Split Plot Design (SPD) with three replications. The treatments of the experiment were three nitrogen doses viz. 75, 100 and $125 \mathrm{~kg} / \mathrm{ha}$ and three plant to plant spacing viz. $10 \mathrm{~cm}$, $15 \mathrm{~cm}$ and $20 \mathrm{~cm}$. The unit plot size was $3.6 \mathrm{~m} \times 3 \mathrm{~m}$. Seeds of okra were sown on 10 March 2015. Intercultural operations were done as and when necessary. Data of plant growth and yield contributing characters were recorded from ten randomly selected plants, but yield was recorded on plot basis. Experimental data were subjected to statistical analysis appropriate to the design using procedure developed by Finney and tests of significance were applied.

\section{Results and discussion}

\subsection{Plant Height :(cm)}

The data in revealed that the effect of nitrogen, the treatment N100 produced significantly maximum plant height $(92.1 \mathrm{~cm})$ as compared to treatment N75 $(84.1 \mathrm{~cm})$ and it was found at par with nitrogen level N125 $(92.4 \mathrm{~cm})$. In case of different plant spacing on height of plant was found to be non significant. The S10 spacing results in maximum average height of plant $(91.3 \mathrm{~cm})$. However, the minimum height $(87.5 \mathrm{~cm})$ was recorded under the S20 spacing. The interaction effects due to spacing and nitrogen levels on plant height was found to be significant, the maximum height of plant $(94.3 \mathrm{~cm})$ was recorded with the combination of N100 and S10. The minimum height of plant $(82.3 \mathrm{~cm})$ was recorded with the treatment combination N75 with spacing S20.The interaction of N100 with S15,S20 and N125 with S10,S15,S20 being at par with N100S10 resulted into significantly better plant height than lower treatment. The favorable effect of spacing and nitrogen in promoting the growth of plant in terms of height of plant might be due to the fact that, closer plant spacing have higher plant density which creates competition among the population for light and resulted into increased in plant height. Amongst the nutrients, nitrogen has the property to enhance the vegetative growth and capacity of plants to utilize the greater amount of nitrogen with increasing dose. This might be due to the higher utilization of nitrogen but in the closer spacing there is no scope for horizontal spread so it might have resulted in the increase in plant height. . [7].

Table 2. Effect of various levels of Nitrogen fertilizer and spacing on the plant height $(\mathrm{cm})$ of okra.

\begin{tabular}{|l|l|l|l|l|}
\hline Treatment & \multicolumn{3}{ll}{ Spacing (cm) } & Mean \\
\hline $\mathbf{N}$ Kg/ha & $\mathbf{S}_{\mathbf{1 0}}$ & $\mathbf{S}_{\mathbf{1 5}}$ & $\mathbf{S}_{\mathbf{2 0}}$ & \\
\hline $\mathbf{N}_{\mathbf{7 5}}$ & 86.0 & 84.0 & 82.3 & 84.1 \\
\hline $\mathbf{N}_{\mathbf{1 0 0}}$ & 94.3 & 92.3 & 89.6 & 92.1 \\
\hline $\mathbf{N}_{\mathbf{1 2 5}}$ & 93.6 & 93.0 & 90.6 & 92.4 \\
\hline Mean & 91.3 & 89.7 & 87.5 & \\
\hline
\end{tabular}

\subsection{Days to $50 \%$ flowering:}

Mean days to flowering decreased gradually with the increasing levels of applied nitrogen from $75 \mathrm{Kg} / \mathrm{ha}$ to $125 \mathrm{Kg} / \mathrm{ha}$. It decreased from 52.7 days to 48.1 days with the increasing level of nitrogen. Similar results were computed in case of spacing that was from spacing S10 to 
S20. The data indicated that the interaction effect of nitrogen and spacing was also significant. The lowest days to $50 \%$ flowering (45.3days) were recorded with $\mathrm{N} 125$ and S20. The treatment consisting of N125 and S15 was at par with N125 and S20. The interaction effects of N100 with S20 and N75 with S20 were at par with each other. [7, 33].

Table 3. Effect of various levels of Nitrogen fertilizer and spacing on the Days to $50 \%$ flowering of okra.

\begin{tabular}{|l|l|l|l|l|}
\hline Treatment & \multicolumn{3}{l|}{ Spacing (cm) } & \\
\hline $\mathbf{N ~ K g / h a ~}$ & $\mathbf{S}_{\mathbf{1 0}}$ & $\mathbf{S}_{\mathbf{1 5}}$ & $\mathbf{S}_{\mathbf{2 0}}$ & Mean \\
\hline $\mathbf{N}_{\mathbf{7 5}}$ & 55.1 & 53.9 & 49.3 & 52.7 \\
\hline $\mathbf{N}_{\mathbf{1 0 0}}$ & 53.0 & 52.1 & 49.3 & 51.5 \\
\hline $\mathbf{N}_{\mathbf{1 2 5}}$ & 50.0 & 48.9 & 45.3 & 48.1 \\
\hline Mean & 52.7 & 51.6 & 48.0 & \\
\hline
\end{tabular}

\subsection{Single pod weight :(g)}

The Nitrogen doses brought about significant increase in fresh weight of fruits when compared with their respective lower levels. The maximum and minimum average fruit weight was noted under $\mathrm{N}_{100}(9.4 \mathrm{~g})$ and $\mathrm{N}_{75}$ $(6.7 \mathrm{~g})$, respectively and at par $(9.8 \mathrm{~g})$ with application of $\mathrm{N}_{125}$. The plant geometry also caused significant effect on the fresh weight of okra fruits. Higher the plant density, lower the fresh weight of okra pods were recorded. As the plant density was lowered the average weight of pods were significantly increased.

Table 4. Effect of various levels of Nitrogen fertilizer and spacing on the Single pod weight (g) of okra.

\begin{tabular}{|l|l|l|l|l|}
\hline Treatment & \multicolumn{3}{l|}{ spacing(cm) } & \\
\hline $\mathbf{N ~ K g / h a ~}$ & $\mathbf{S}_{\mathbf{1 0}}$ & $\mathbf{S}_{\mathbf{1 5}}$ & $\mathbf{S}_{\mathbf{2 0}}$ & Mean \\
\hline $\mathbf{N}_{\mathbf{7 5}}$ & 6.2 & 7.0 & 7.1 & 6.7 \\
\hline $\mathbf{N}_{\mathbf{1 0 0}}$ & 8.2 & 10.2 & 9.8 & 9.4 \\
\hline $\mathbf{N}_{\mathbf{1 2 5}}$ & 9.7 & 9.5 & 10.1 & 9.8 \\
\hline Mean & 8.0 & 8.9 & 9.0 & \\
\hline
\end{tabular}

Low plant density, spacing $\mathrm{S}_{15}$ revealed the significant increase $(8.9 \mathrm{~g})$ in fresh weight of okra fruits. The minimum fresh weight $(8.0 \mathrm{~g})$ was noted under low spacing S10. The data indicated that the interaction effect of nitrogen and spacing was significantly higher from the lower treatment. The highest pod weight of $10.2 \mathrm{~g}$ was obtained with $\mathrm{N}_{100}$ and $\mathrm{S}_{15}$. The interaction effects of $\mathrm{N}_{125}$ with $\mathrm{S}_{10}, \mathrm{~S}_{15}, \mathrm{~S}_{20}$ and $\mathrm{N}_{100}$ with $\mathrm{S}_{20}$ were at par with $\mathrm{N}_{100} \mathrm{~S}_{15}$ for single pod weight. [38, 24].

\subsection{Leaves per plant:}

The treatment $\mathrm{N}_{100}$ recorded maximum leaves per plant (22.2) and it was at par with treatment $\mathrm{N}_{125}$ having 23.4 leaves per plant. However, minimum leaves per plant (19.3) were recorded in the treatment $\mathrm{N}_{75}$. An increase in nitrogen supply induced more leaves per plant. The average leaves per plant (22.8) were found to be maximum in the spacing $\mathrm{S}_{20}$. However, average minimum leaves per plant (20.6) were recorded in the spacing $S_{10}$. Wider spacing provided more space for growth, which increased the number of branches per plant, and ultimately increases the number of leaves per plant. The interaction effects due to spacing and nitrogen levels on leaves per plant were found to be significant. Combination of $\mathrm{N}_{125}$ nitrogen with spacing $\mathrm{S}_{20}$ proved to be the overall best treatment which increased leaves per plant (24.6) from other combination of treatments. The interaction of $\mathrm{N}_{125}$ with $\mathrm{S}_{15}, \mathrm{~S}_{10}$ being at par with $\mathrm{N}_{125} \mathrm{~S}_{20}$ treatment. The interaction of $\mathrm{N}_{100}$ with $\mathrm{S}_{20}, \mathrm{~S}_{10}$ being at par with each other. . $[12,25]$.

Table 5. Effect of various levels of nitrogen fertilizer and spacing on the leaves per plant (No) of okra.

\begin{tabular}{|c|c|c|c|c|}
\hline Treatment & Spac & (cm) & & \\
\hline $\mathbf{N ~ K g / h a}$ & $\mathbf{S}_{10}$ & $S_{15}$ & $\mathbf{S}_{20}$ & Mean \\
\hline $\mathbf{N}_{75}$ & 17.0 & 20.3 & 20.6 & 19.3 \\
\hline $\mathbf{N}_{100}$ & 22.3 & 21.0 & 23.3 & 22.2 \\
\hline $\mathbf{N}_{125}$ & 22.6 & 23.0 & 24.6 & 23.4 \\
\hline Mean & 20.6 & 21.4 & 22.8 & \\
\hline
\end{tabular}

\subsection{Number of green fruits per plant::}

Average numbers of fruits per plant were significantly influenced by nitrogen application. Significantly higher numbers of fruits per plant (31.2) were obtained with application of $100 \mathrm{~kg} \mathrm{~N}$ per hectare and highest number of fruits per plant (36.7) with application of $125 \mathrm{~kg} \mathrm{~N}$ per hectare. The plant under application of $75 \mathrm{~kg} \mathrm{~N}$ per hectare showed significantly minimum (22.3) number of fruits per plant. The plant population affected the production of fruits per plant significantly. Wider spacing expressed significantly greater number of fruits per plant The maximum and minimum number of fruits as influenced by plant density were recorded under $\mathrm{S}_{20}(31.5)$ and $\mathrm{S}_{10}(28.8)$ spacing, respectively. The significantly increased number of fruits per plant (30.1) was noticed under spacing $\mathrm{S}_{15}$. The data indicated that nitrogen and spacing interaction was significant. The highest number of pods per plant (40.2) was obtained with combination of $\mathrm{N}_{125}$ and $\mathrm{S}_{20}$ which was significantly the best than all other nitrogen and spacing combinations. The interaction effects of $\mathrm{N}_{125}$ with $\mathrm{S}_{10}, \mathrm{~S}_{15}$ and $\mathrm{N}_{100}$ with $\mathrm{S}_{10}, \mathrm{~S}_{15}, \mathrm{~S}_{20}$ was at par with each other and superior than the lower treatment. . [7, 34].

Table 6. Effect of various levels of nitrogen fertilizer and spacing on number of green pods per plant (No) of okra.

\begin{tabular}{|l|l|l|l|l|}
\hline Treatment & \multicolumn{2}{l|}{ Spacing (cm) } & \\
\hline $\mathbf{N ~ K g / h a ~}$ & $\mathbf{S}_{\mathbf{1 0}}$ & $\mathbf{S}_{\mathbf{1 5}}$ & $\mathbf{S}_{\mathbf{2 0}}$ & Mean \\
\hline $\mathbf{N}_{\mathbf{7 5}}$ & 21.6 & 22.0 & 23.3 & 22.3 \\
\hline $\mathbf{N}_{\mathbf{1 0 0}}$ & 30.6 & 32.3 & 30.6 & 31.2 \\
\hline $\mathbf{N}_{\mathbf{1 2 5}}$ & 34.3 & 36.0 & 40.3 & 36.7 \\
\hline Mean & 28.8 & 30.1 & 31.4 & \\
\hline
\end{tabular}




\subsection{Number of nodes per plant:}

Number of nodes on main stem were significantly increased, as nitrogen applications increased from 75 $\mathrm{kg} / \mathrm{ha}$ to $100 \mathrm{~kg} / \mathrm{ha}$ and at par with higher dose of nitrogen i.e. $125 \mathrm{~kg} / \mathrm{ha}$. The maximum and minimum numbers of nodes were 36.3 and 29.5 respectively. Significantly increased number of nodes per plant was (35.8) when the nitrogen level was $\mathrm{N}_{100}$. The minimum and maximum numbers of nodes per plant were recorded under spacing of $\mathrm{S}_{10}$ (32.8) and $\mathrm{S}_{20}$ (34.6), respectively. Significantly increased number of nodes per plant was (34.2) when the spacing was $S_{15}$. The higher number of nodes per plant (37.1) was recorded with combination of $\mathrm{N}_{125}$ and $\mathrm{S}_{20}$. The interaction of $\mathrm{N}_{125}$ with $\mathrm{S}_{10}, \mathrm{~S}_{15}$ and $\mathrm{N}_{100}$ with $\mathrm{S}_{15}, \mathrm{~S}_{20}$ were at par with $\mathrm{N}_{125} \mathrm{~S}_{20}$. [11, 12].

Table 7. Effect of various levels of nitrogen fertilizer and spacing on number of nodes per plant (No) of okra.

\begin{tabular}{|l|l|l|l|l|}
\hline Treatment & \multicolumn{2}{l|}{ Spacing (cm) } & \\
\hline $\mathbf{N ~ K g / h a}$ & $\mathbf{S}_{\mathbf{1 0}}$ & $\mathbf{S}_{\mathbf{1 5}}$ & $\mathbf{S}_{\mathbf{2 0}}$ & Mean \\
\hline $\mathbf{N}_{\mathbf{7 5}}$ & 28.6 & 30.0 & 30.0 & 29.5 \\
\hline $\mathbf{N}_{\mathbf{1 0 0}}$ & 34.6 & 36.0 & 37.0 & 35.8 \\
\hline $\mathbf{N}_{\mathbf{1 2 5}}$ & 35.3 & 36.6 & 37.1 & 36.3 \\
\hline Mean & 32.8 & 34.2 & 34.6 & \\
\hline
\end{tabular}

\subsection{Green fruit yield per plant:}

Green fruit yield per plant was increased with the increased dose of nitrogen from $75 \mathrm{~kg} / \mathrm{ha}$ to $125 \mathrm{~kg} / \mathrm{ha}$. Significantly higher fruit yield per plant was recorded under $\mathrm{N}_{100}$ which was $302 \mathrm{~g}$. The minimum fruit yield per plant was $164 \mathrm{~g}$ at application of $75 \mathrm{Kg} \mathrm{N} / \mathrm{ha}$. Wider spacing expressed significantly greater green fruit yield per plant. The maximum and minimum green fruit yield per plant as influenced by plant density were recorded under $\mathrm{S}_{20}(283 \mathrm{~g})$ and $\mathrm{S}_{10}(251 \mathrm{~g})$ spacing, respectively. Significant increase in green fruit yield per plant $(272 \mathrm{~g})$ was noted at the spacing of $S_{10}$. The higher number of fruit yield per plant $(355 \mathrm{~g})$ was recorded with combination of $\mathrm{N}_{125} \mathrm{~S}_{20}$. The interaction of $\mathrm{N}_{125}$ with $\mathrm{S}_{10}$, and $\mathrm{S}_{15}$ were at par with combination of $\mathrm{N}_{125}$ and $\mathrm{S}_{20}$. The interaction of $\mathrm{N}_{100}$ with $\mathrm{S}_{10}, \mathrm{~S}_{15}, \mathrm{~S}_{20}$ were at par with each other. [30].

Table 8. Effect of various levels of nitrogen fertilizer and spacing on green fruit yield per plant (g) of okra.

\begin{tabular}{|l|l|l|l|l|}
\hline Treatment & \multicolumn{3}{l|}{ Spacing (cm) } & \\
\hline $\mathbf{N ~ K g} / \mathbf{h a}$ & $\mathbf{S}_{\mathbf{1 0}}$ & $\mathbf{S}_{\mathbf{1 5}}$ & $\mathbf{S}_{\mathbf{2 0}}$ & Mean \\
\hline $\mathbf{N}_{\mathbf{7 5}}$ & 146.6 & 165.0 & 182.6 & 164.7 \\
\hline $\mathbf{N}_{\mathbf{1 0 0}}$ & 288.6 & 306.6 & 313.0 & 302.7 \\
\hline $\mathbf{N}_{\mathbf{1 2 5}}$ & 340.0 & 344.6 & 355.0 & 346.5 \\
\hline Mean & 251.7 & 272.0 & 283.5 & \\
\hline
\end{tabular}

\subsection{Pod length :( $\mathrm{cm})$}

The increase in nitrogen levels up to $\mathrm{N}_{100}$ brought about significant improvement in pod length of okra. The maximum and minimum fruit length was recorded under $\mathrm{N}_{100}(9.4 \mathrm{~cm})$ and $\mathrm{N}_{75}(6.8 \mathrm{~cm})$, respectively, which was at par with treatment $\mathrm{N}_{125}(9.9 \mathrm{~cm})$. The closer spacing expressed significantly shorter fruits when compared with wider spacing. Maximum and minimum pod lengths were procured under spacing $S_{20}(9.0 \mathrm{~cm})$ and spacing $S_{10}(8.3$ $\mathrm{cm})$, respectively. The maximum pod length of $10.3 \mathrm{~cm}$ was produced by the combined effect of $\mathrm{N}_{125}$ and $\mathrm{S}_{20}$ which was significantly higher than all other combinations. The interaction effect of $\mathrm{N}_{125}$ with $\mathrm{S}_{15}, \mathrm{~S}_{10}$ and $\mathrm{N}_{100}$ with $\mathrm{S}_{15}, \mathrm{~S}_{20}$ being at par with $\mathrm{N}_{125}$ and $\mathrm{S}_{20}$ significantly produced longer pod than lower treatment. [4].

Table 9. Effect of various levels of nitrogen fertilizer and spacing on pod length $(\mathrm{cm})$ of okra.

\begin{tabular}{|l|l|l|l|l|}
\hline Treatment & \multicolumn{3}{l|}{ Spacing (cm) } & \\
\hline $\mathbf{N}$ Kg/ha & $\mathbf{S}_{\mathbf{1 0}}$ & $\mathbf{S}_{\mathbf{1 5}}$ & $\mathbf{S}_{\mathbf{2 0}}$ & Mean \\
\hline $\mathbf{N}_{\mathbf{7 5}}$ & 6.5 & 6.9 & 7.0 & 6.8 \\
\hline $\mathbf{N}_{\mathbf{1 0 0}}$ & 8.5 & 10.2 & 9.6 & 9.4 \\
\hline $\mathbf{N}_{\mathbf{1 2 5}}$ & 10.0 & 9.5 & 10.3 & 9.9 \\
\hline Mean & 8.3 & 8.9 & 9.0 & \\
\hline
\end{tabular}

\subsection{Pod diameter :( cm)}

The diameter of pod were recorded by using venire caliper and the means were worked out and expressed in $\mathrm{cm}$. Application of higher levels of nitrogen that was $\mathrm{N}_{100}$ $(1.50 \mathrm{~cm})$ and $\mathrm{N}_{125}(1.86 \mathrm{~cm})$ proved more effective in respect of diameter when compared with $\mathrm{N}_{75}(1.05 \mathrm{~cm})$. The maximum diameter of pod was produced with $\mathrm{N}_{100}$ dose. $[1,29]$.

Table 10. Effect of various levels of nitrogen fertilizer and spacing on pod diameter $(\mathrm{cm})$ of okra

\begin{tabular}{|c|c|c|c|c|}
\hline Treatment & Spac & & & \\
\hline $\mathbf{N ~ K g / h a}$ & $\mathbf{S}_{10}$ & $S_{15}$ & $\mathbf{S}_{20}$ & Mean \\
\hline $\mathbf{N}_{75}$ & 0.96 & 1.06 & 1.13 & 1.05 \\
\hline $\mathbf{N}_{\mathbf{1 0 0}}$ & 1.43 & 1.46 & 1.60 & 1.50 \\
\hline $\mathbf{N}_{125}$ & 1.76 & 1.88 & 1.95 & 1.86 \\
\hline Mean & 1.38 & 1.47 & 1.56 & \\
\hline
\end{tabular}

\subsection{Internode length : $(\mathrm{cm})$}

The mean internode length increased gradually with the increasing level of applied nitrogen. It increased from $2.16 \mathrm{~cm}$ in plot applied with nitrogen dose of $\mathrm{N}_{75}$ to 2.82 $\mathrm{cm}$ and $3.04 \mathrm{~cm}$ with nitrogen application of $\mathrm{N}_{100}$ and $N_{125}$ respectively. Significant increase was noticed with increased dose of nitrogen $\mathrm{N}_{100}$. The internode length was significantly influenced by within row spacing of plants. But spacing has opposite effect on internode length. Internode length decreases from $3.0 \mathrm{~cm}$ to $2.5 \mathrm{~cm}$ and to 
$2.4 \mathrm{~cm}$ when spacing is increased from $S_{10}$ to $S_{15}$ and to $\mathrm{S}_{20}$ respectively.

Table 11. Effect of various levels of nitrogen fertilizer and spacing on internode length $(\mathrm{cm})$ of okra.

\begin{tabular}{|l|l|l|l|l|}
\hline Treatment & \multicolumn{3}{l|}{ |l|l|l|} & \\
\hline $\mathbf{N ~ K g} / \mathbf{h a}$ & $\mathbf{S}_{\mathbf{1 0}}$ & $\mathbf{S}_{\mathbf{1 5}}$ & $\mathbf{S}_{\mathbf{2 0}}$ & Mean \\
\hline $\mathrm{N}_{75}$ & 2.4 & 2.0 & 2.0 & 2.1 \\
\hline $\mathrm{N}_{100}$ & 3.2 & 2.7 & 2.4 & 2.8 \\
\hline $\mathrm{N}_{125}$ & 3.3 & 2.9 & 2.8 & 3.0 \\
\hline Mean & 3.0 & 2.5 & 2.4 & \\
\hline
\end{tabular}

The maximum internode length of $3.30 \mathrm{~cm}$ was produced by the combined effect of N125 and $\mathrm{S} 10 \mathrm{~cm}$ which was significantly higher than all other combinations. The interaction effect of N125 with S15 and N100 with S10, being at par with $\mathrm{N} 125$ and S10 significantly produced longer internode. The interaction effects of N100 with S15 and N125 with S20 being at par with each other. The increase in internode length at higher level of nutrients in the present study might be due to higher absorption of nutrients, especially nitrogen which enhanced the cell division, cell elongation with concomitant increase in metabolic activity by which meristmatic activity of tissue increased manifold and led to increase in internode length. [28].

\subsection{Total green pod yield :( $q / h a)$}

The yield of green pods was noted significantly greater (72.4 q) under $\mathrm{N}_{100}$ and at par with $\mathrm{N}_{125}$ (76.0 q) against the minimum (53 q) recorded under lower level $\mathrm{N}_{75}$. Regarding the plant density, $\mathrm{S}_{20}$ spacing produced the highest yield (68.7 q) against the minimum (64.4 q) recorded under $S_{10}$ spacing. Significantly increase in yield $\left(68.2\right.$ q) was noted under $\mathrm{S}_{15}$ spacing. The maximum total green pod yield $(77.6 \mathrm{q} / \mathrm{ha})$ was produced by the combined effect of $\mathrm{N}_{125}$ and $\mathrm{S}_{15}$ spacing which was significantly higher than all other combinations. The interaction effect of $\mathrm{N}_{25}$ with $\mathrm{S}_{10}, \mathrm{~S}_{20}$ and $\mathrm{N}_{100}$ with $\mathrm{S} 20$ being at par with $\mathrm{N}_{125} \mathrm{~S}_{15}$ combination significantly. The significant increase in total yields might also be attributed to the increased branching as pod developed in the axils of every branch once flowering has began. Number of nodes per plant also increased with fertilizer application along with optimum spacing of $15 \mathrm{~cm}$ with-in row plant spacing. Since every node has a potential to produce flower which directly influence the yield per plot. $[5,17$, 24].

Table 12. Effect of various levels of nitrogen fertilizer and spacing on total green pod yield $(\mathrm{q} / \mathrm{ha})$ of okra.

\begin{tabular}{|c|c|c|c|c|}
\hline Treatmen & \multicolumn{3}{|c|}{ Spacing (cm) } & \\
\hline N Kg/ha & S10 & S15 & S20 & Mean \\
\hline N75 & 49.6 & 54.0 & 55.3 & 53.0 \\
\hline N100 & 69.3 & 73.0 & 75.0 & 72.4 \\
\hline N125 & 74.3 & 77.6 & 76.0 & 76.0 \\
\hline
\end{tabular}

\begin{tabular}{|l|l|l|l|l|}
\hline Mean & 64.4 & 68.2 & 68.7 & \\
\hline
\end{tabular}

\subsection{Benefit cost ratio analysis of okra}

Analysis of cost and return revealed that the gross and net returns were higher at higher doses of $\mathrm{N}$ and spacing. The highest gross return (Rs.94080) and net return (Rs.84621.3) were obtained from N125S20. The BCR was also higher (9.54) under the same treatment combination. [39].

Table 13. Effect of nitrogen and spacing on benefit cost ratio analysis of okra yield..

\begin{tabular}{|c|c|c|c|c|c|c|}
\hline $\begin{array}{l}\mathrm{S} . \\
\mathrm{N}\end{array}$ & $\begin{array}{l}\text { Treatmen } \\
\mathrm{t}\end{array}$ & $\begin{array}{l}\text { Yield } \\
(\mathrm{t} / \mathrm{ha})\end{array}$ & $\begin{array}{l}\text { Cost of } \\
\text { cultivatio } \\
\mathrm{n} \\
(\mathrm{t} / \mathrm{ha})\end{array}$ & $\begin{array}{l}\text { Gross } \\
\text { incom } \\
\mathrm{e} \\
\text { (t/ha) } \\
\end{array}$ & $\begin{array}{l}\text { Net } \\
\text { returns } \\
\text { (t/ha) }\end{array}$ & $\begin{array}{l}\text { Benefi } \\
t \text { cost } \\
\text { ratio }\end{array}$ \\
\hline 1 & $\mathrm{~N}_{75} \mathrm{~S}_{10}$ & 51.9 & 17715.2 & $\begin{array}{l}6228 \\
0\end{array}$ & $\begin{array}{l}44564 . \\
8\end{array}$ & 3.51 \\
\hline 2 & $\mathrm{~N}_{75} \mathrm{~S}_{15}$ & 54.0 & 12065.2 & $\begin{array}{l}6480 \\
0\end{array}$ & $\begin{array}{l}52734 . \\
8\end{array}$ & 5.37 \\
\hline 3 & $\mathrm{~N}_{75} \mathrm{~S}_{20}$ & 55.3 & 8915.2 & $\begin{array}{l}6636 \\
0\end{array}$ & $\begin{array}{l}57444 . \\
8\end{array}$ & 7.44 \\
\hline 4 & $\mathrm{~N}_{100} \mathrm{~S}_{10}$ & 69.3 & 17986.9 & $\begin{array}{l}8316 \\
0\end{array}$ & $\begin{array}{l}65173 . \\
1\end{array}$ & 4.62 \\
\hline 5 & $\mathrm{~N}_{100} \mathrm{~S}_{15}$ & 73.0 & 12336.9 & $\begin{array}{l}8760 \\
0\end{array}$ & $\begin{array}{l}75263 . \\
1\end{array}$ & 7.10 \\
\hline 6 & $\mathrm{~N}_{100} \mathrm{~S}_{20}$ & 75.0 & 9186.9 & $\begin{array}{l}9000 \\
0\end{array}$ & $\begin{array}{l}80813 . \\
1\end{array}$ & 9.79 \\
\hline 7 & $\mathrm{~N}_{125} \mathrm{~S}_{10}$ & 74.3 & 18258.7 & $\begin{array}{l}8916 \\
0\end{array}$ & $\begin{array}{l}70901 . \\
3\end{array}$ & 4.88 \\
\hline 8 & $\mathrm{~N}_{125} \mathrm{~S}_{15}$ & 77.6 & 12608.7 & $\begin{array}{l}9312 \\
0\end{array}$ & $\begin{array}{l}80511 . \\
3\end{array}$ & 7.38 \\
\hline 9 & $\mathrm{~N}_{125} \mathrm{~S}_{20}$ & 78.4 & 9458.7 & $\begin{array}{l}9408 \\
0\end{array}$ & $\begin{array}{l}84621 . \\
3\end{array}$ & 9.94 \\
\hline & $\begin{array}{l}\text { C.D } \\
(p=0.05 \\
)\end{array}$ & 3.92 & & & & \\
\hline
\end{tabular}

a. Price of okra: Rs. 12.00

b. BCR: $\frac{\text { Gross return }}{\text { Cost of production }}$

\section{Conclusion}

On the basis of both individual and combined effects of nitrogen and spacing, $100 \mathrm{~kg} \mathrm{~N} / \mathrm{ha}$ and $15 \mathrm{~cm}$ plant to plant spacing may be considered optimum for obtaining high yield with good quality. So, this proposal is useful for improving the productivity profitability of okra growers in Punjab. 


\section{References}

1. A.O.A.C..Officil Methods of Analysis, XIV Edition, Washington, (D.C) Barnah G.K.S. Response of okra varieties to different plant spacing in hill zone of Assam. Haryana Journal of Horticultural Sciences, 26 (1-2): 130-134. (1984)

2. Absar, N. and M.A. Siddique. Influence of plant density on the yield of three varieties of okra.Bangladesh J. Agric. 7(3-4):15-21. (1982)

3. Ahamad,N. and L.I. Tulloch-Reid. Effect of fertilizer nitrogen, phosphorus, potassium and magnesium on yield and nutrient content of okra (Hibiscus esculentus L.). Agron.J. , 60:353_356. (1968)

4. Amjad, A. Anjum, M.A. and Hussain, S. Effect of different sowing dates and various doses of fertilizer on juvenility and productivity of okra. Pakistan J.Agril.Sci., 38 (1-2),29-32. (2001)

5. Babatola LA, Ojo DO, Adewoyin OB. Effect of NPK 20:10:10 fertilizer levels on the yield of okra-sweetcorn intercrop and post harvest quality of okra. Proc. Hortic. Soc. Nig. Conf. pp 74-78. (2002)

6. Babatola, L.A. and J.O. Olaniyi. Effect of NPK 15-15-15-fertilizer level and plant spacing on performance and shelf life of okra. In: proc. HORTSON conference, NIHORT, Ibadan. (1997).

7. Birbal, Nehra, B.k. and Malik, Y.S. Effect of spacing and nitrogen on fruit yield of okra (Abelmoschus esculentus (L) Moench) cv. Varasha Uphar. Haryana Agric. Univ. J.Res., 25, 47-51. (1995)

8. Chattopadhyay, A. and B.C. Sahana. Response of okra seed crop to nitrogen and phosphorous fertilization in acidic soil of old Alluvial Zone, West Bengal.res,crops, 1(2),176-180. (2000)

9. Dademal AA, Dangale JH, Mhaskar NV. Effect of manures and fertilizers content and uptake of nutrients by okra on laterilic soil of konkan. J. soils and crops. 14 (2): 262-268. (2004)

10. Decoteau DR, Graham HAH.Plant spatial arrangements affect growth, yield and pod distribution of cayenne peppers. Hort Sci, 29: 149-151. (1994)

11. Gupta A. Response of spring planted okra to varying of irrigation and plant spacing. Veg Sci, 17: 16-19. (1990)

12. Gupta, A., K. Srinivas and V. Shukla. Response okra (Abelmoschus esculentus L. Moench) to plant spacing and nitrogen, phosphorus fertilization. Indian J. Horti. Sci. 38 (3-4):218-222.(1981)

13. Hermann M, Makadji M, Daunicht HJ. Effect of intra-row spacing on time course of growth and fruit yield of okra. Scientia Hort , 45: 37-48. (1990)

14. Hooda, R.S., M.L Pandita., Kalloo and A.S. Sindhu. Effect of spacing and nitrogen on the growth and yield of tomato variety HS-110.
Harayana Journal of Horticultural Sciences, 13 (1-2): 48-49. (1984)

15. Kahn BA, Cooksey JR, Motes JE. Within-row spacing effects on traits of importance to mechanical harvest in paprika pepper. Scientia Hort, 69: 31-39. (1997)

16. Khan, A.R. and R.C. Jasiwal. Effect of nitrogen, spacing and green fruit picking in the seed production of okra (Abelmoschus esculentus L. Moench) Vegetable Sciences, 15(1): 8-14. (1988)

17. Kolawole GO, Olapede AO, Alade CR, Olaniyi JO. Response of okra (Abelmoschus esculentus ) varieties to NPK fertilizer in the South Guinea Savanna of Nigeria. Niger. J. Horticult. Sci. 13: 99-108. (2008)

18. M.D. Hossain, M.a. Rahman, M.m. Hoque, M.s. Islam and M.a. Salam. Year round okra production and economic return as influenced by spacing in Barisal Region" Bangladesh J. Agric. Res.26.pp.319-328. (2001)

19. Mohanta, H. C. Effect of phosphorus and genotypes on the yield and contributing characters in okra (Abelmoschus esculentus L. Moench). M S. Thesis, Dept. of Horticulture, IPSA, Salna, Gazipur. (1998)

20. Meyer, B. S. and D. B. I Anderson. Plant Physiology. East West Press Pvt. Ltd., New Delhi. (1970)

21. Majanbu, I. S.; V. B. Ogunlela; M. K. Abmed and J. D. Olarewaju. Response of two okra varieties to fertilizers, yield and yield components as influenced by nitrogen and phosphorus application. Fertilizer Res. 6 (3): 257-267. (1985)

22. Mangual, G. and F.W. Martin. Effect of spacing on seed,protein and oil production of four okra varieties.J.Agric.Univ.Puerto Rico,64:450-490. (1980)

23. Mani, S., Ravel, R. and Shukla, V. Effect of nitrogen and phosphorus on yield and chemical composition of okra. Geobios New Reports, 2 (2-3): 56 -59. (1981)

24. Olasantan, F.O. Optimum plant populations for okra in mixture with cassava and its relevance to rainy season based cropping system in southwestern Nigeria. Tournal of Agri cultural sci. 136:207-214. (2001)

25. Omotosho SO, Shittu OS. Effect of NPK fertilizer rates and method of application on growth and yield of okra (Abelmoschus esculentus (L.) Moench). Res.J.Agron. 1(2) 8487. (2007)

26. Palanisamy, V., Vanangamud, T. Jayraj, T. and T.V. Karivarthraju. Influence of date of sowing and spacing on seed quality in bhindi [Abelmoschus esculentus (L.) Moench]. South Indian Horticulture, 34 (1): 23 -25. (1986)

27. Paliwal, R., I. S. Naruka and J.K. Yadav. Effect of nitrogen and sulphur on growth and yield of okra (Abelmoschus esculentus L. Moench.) cv. Pusa sawani. Prog.Hort, . 31(1-2), 94-97. (1999) 
28. Pandey BR, Sharma RK, Sharma RS. Influence of plant spacing and nitrogen level on growth, yield attributes and seed yield of okra during spring season. Veg Sci, 21(1): 12-15. (1994)

29. Randhawa, G.S. and Pannu, M.S. The effect of row spacing and levels of nitrogen on the growth and yield of okra (Abelmoschus esculentus L. Moench). Journal of Research, 6: 320-324. (1969)

30. Rahman, M.M., Roy, S. k. and Quasem, A. Effet of plant population and nitrogen on the yield and yield attributes of okra. Bagladesh Agro. J., 4(1 \& 2), 7-12. (1992).

31. Randhawa, G.S. and Pannun, M.S. The effect of row spacing and level of nitrogen on the growth and yield of okra (Abelmoshus esculentus L. Moench). J.Res .Ludhiana 6: 304-4. (1969)

32. Rastogi,K.B., P.P. Sharma, N. P. Singh, B.N. korla. Effect of different levels of nitrogen and plant and spacing on seed yield of okra (Abelmoschus esulentus L. Monech). Vegetable Sci. 14 (2): 120-123. (1987)

33. Saimbhi,M.S., S.P. Jasiwal, K.S. Nandpuri and G. Kaur. Effect of phorate and $\mathrm{N}$ on plant growth, seed yield and chemical composition of okra. Indian J. Agric.Sci. , 43: 930-933. (1975)

34. Singh, K. and B.K. Srivastava. Effect of various levels of nitrogen and phosphorus on growth and yield of chilli (Capsicum annuum L). Indian Journal of Horticulture, 45 (3-4): 319324. (1988)

35. Singh, N.P. Effect of nitrogen, phosphorus and potassium on bhindi (Abelmoschus esculentus L. Moench).Prog.Hort. , 10:21-30. (1979)

36. Singh, S.K., Rai, B., Singh, S. and Singh, M.B. Effect of plant spacing and nitrogen fertilization on growth and fruit yield of hybrid brinjal. Silver Jubilee National Symposium on Emerging Scenario in Vegetable Research and Development, 12-14 Dec. RD.V.R. Varanasi: 143. (1998)

37. Suwandi. Effect of N, P and K (15-15-15) fertilizer and planting distance on the growth and yield of the tomato cvs. GH2 and GH4 (Mutiara). Bull Penelition Hort., 16 (2) : 1118.(1988)

38. Yadav, P., Singh, P. and Yadav, R.L. Effect of organic manure and nitrogen levels on growth, yield and quality of okra [Abelmoschus esculentus (L.) Moehch]. Indian Journal of Horticulture, 63 (2): 215-217. (2006)

39. Z. A. Firoz. Impact of nitrogen and phosphorus on the growth and yield of okra. Bangladesh J. Agril. Res. 34(4): 713-722. (2009) 